\title{
Taxonomic notes on spiders (Arachnida: Aranei) of the Russian Far East
}

\section{Таксономические заметки по паукам (Arachnida: Aranei) Аальнего Востока России}

\author{
Yuri M. Marusik ${ }^{1,2}$, Kirill G. Mikhailov ${ }^{3}$, Mikhail M. Omelko ${ }^{4,5}$ \\ Ю.М. Марусик ${ }^{1,2}$, К.Г. Михайлов ${ }^{3}$ М.М. Омелько
}

\footnotetext{
${ }^{1}$ Institute for Biological Problems of the North, Portovaya Str. 18, Magadan 685000 Russia. E-mail: yurmar@mail.ru

${ }^{2}$ Zoological Museum, University of Turku, FI-20014 Turku, Finland. E-mail: sepkopo@utu.fi

${ }^{3}$ Zoological Museum MGU, Bolshaya Nikitksaya Str. 6, Moscow 125009 Russia. E-mail: mikhailov2000@gmail.com

${ }^{4}$ Gornotaezhnaya Station FEB RAS, Gornotaezhnoe Vil., Ussuriysk Dist., Primorski Krai 692533 Russia. E-mail: omelkom@gmail.com

${ }^{5}$ Far Eastern Federal University, Sukhanova 8, Vladivostok 690950 Russia.

${ }^{1}$ Институт биологических проблем Севера ДВО РАН, ул. Портовая 18, Магадан 685000, Россия.

2 Зоологический музей, университет Турку, FI-20014 Турку, Финляндия.

3 Зоологический музей МГУ им. М.В. Ломоносова, ул. Большая Никитская, 6, Москва 125009 Россия.

${ }^{4}$ Дальневосточный федеральный университет, Суханова 8, Владивосток, 690950, Россия.

${ }^{5}$ Горнотаёжная станция ДВО РАН, с. Горнотаёжное, Уссурийский район, Приморский край, 692533, Россия.
}

KEY WORDS: Araneae, new synonym, new combination, new status, Far East Asia.

КЛЮЧЕВЫЕ СЛОВА: Аraneae, новый синоним, новая комбинация, новый статус, Дальний Восток.

ABSTRACT: Eight species and one genus are synonymized: Micryphantes miniatus Grube, 1861, syn.n. = Hypomma bituberculatum (Wider, 1834); Linyphia melanopleuros Grube, 1861, syn.n. = Megalepthyphantes nebulosus (Sundevall, 1830); Linyphia albomaculata Grube, 1861, syn.n. = Neriene emphana (Walckenaer, 1841); Pardosa bukukun Logunov et Marusik, 1995, syn.n. $=P$. hanrasanensis Jo et Paik, 1984; Attus dimidiatus Grube, 1861, syn.n. = Carrhotus xanthogramma (Latreille, 1819); Phoroncidia minschana (Schenkel, 1936), syn.n. = Ph. pilula (Karsch, 1879); Steatoda amurica (Strand, 1907), syn.n. = S. albomaculata (De Geer, 1778); Attus fuscostriatus Grube, 1861, syn.n. = Neon reticulatus (Blackwall, 1853); Orientopus Eskov, 1992, syn.n. = Silometopoides Eskov, 1990. A new status (genus) is suggested for Theoneta Eskov et Marusik, 1991 earlier considered a subgenus of Microneta Menge, 1869 with two species M. (T.) aterrima Eskov et Marusik, 1991 and M. (T.) saaristoi Eskov et Marusik, 1991. Pardosa hanrasanensis Jo et Paik, 1984 is removed from synonymy with $P$. bifasciata (C.L. Koch, 1834). Four names are removed from synonymy with Sitticus avocator (O. Pickard-Cambridge, 1885): Attus viduus Kulczyński, 1895, Sitticus numeratus Bösenberg et Strand, 1906, S. sibiricus Roewer, 1951 and S. paraviduus Schenkel, 1963; all are synonymized with $S$. distinguendus (Simon, 1868).

РЕЗЮМЕ: Установлены 8 видовых и 1 родовой синоним: Micryphantes miniatus Grube, 1861, syn.n. = Hypomma bituberculatum (Wider, 1834); Linyphia melanopleuros Grube, 1861, syn.n. = Megalepthy- phantes nebulosus (Sundevall, 1830); Linyphia albomaculata Grube, 1861, syn.n. = Neriene emphana (Walckenaer, 1841); Pardosa bukukun Logunov et Marusik, 1995, syn.n. $=$ P. hanrasanensis Jo et Paik, 1984; Attus dimidiatus Grube, 1861, syn.n. = Carrhotus xanthogramma (Latreille, 1819); Phoroncidia minschana (Schenkel, 1936), syn.n. = Ph. pilula (Karsch, 1879); Steatoda amurica (Strand, 1907), syn.n. $=S$. albomaculata (De Geer, 1778); Attus fuscostriatus Grube, 1861, syn.n. = Neon reticulatus (Blackwall, 1853); Orientopus Eskov, 1992, syn.n. = Silometopoides Eskov, 1990. Новый статус (род) предложен для таксона Theoneta Eskov et Marusik, 1991, ранее рассматриваемого как подрод Microneta Menge, 1869, с двумя видами: M. (T.) aterrima Eskov et Marusik, 1991 и M. (T.) saaristoi Eskov et Marusik, 1991. Название Pardosa hanrasanensis Jo et Paik, 1984 выведено из синонимии к P. bifasciata (C.L. Koch, 1834). Четыре названия выведены из синонимии к Sitticus avocator (O. Pickard-Cambridge, 1885): Attus viduus Kulczyński, 1895, Sitticus numeratus Bösenberg et Strand, 1906, S. sibiricus Roewer, 1951 и $S$. paraviduus Schenkel, 1963; все они сведены в синонимы к $S$. distinguendus (Simon, 1868).

\section{Introduction}

Spiders occurring in the south part of the continental Russian Far East, from Amur and Jewish Areas, Khabarovsk and Primorsky Provinces, are relatively well studied. Eight hundred sixty-four spider species are reported from this region [Mikhailov, 2013]. Of 24 


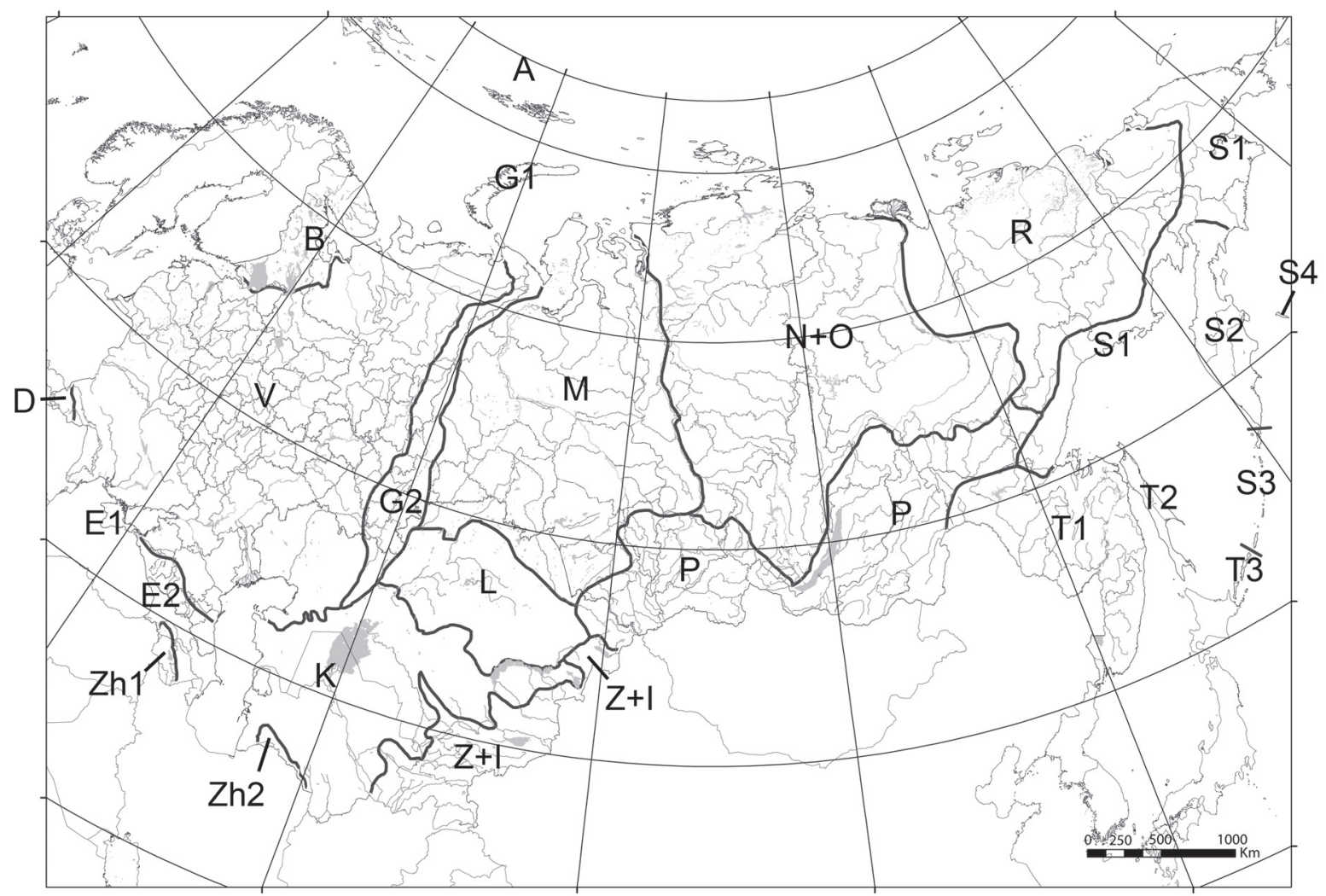

Map 1. Physiographical subregions of the former Soviet Union showing limits of the south part of the Russian Far East (T1) and its relative size (after Mikhailov [2013], modified).

Карта 1. Физико-географические регионы бывшего СССР, показаны границы юга Дальнего Востока (Т1) и его относительный размер (по: Mikhailov [2013], изменено).

physiographical subregions of Russia and republics of the former Soviet Union (Map 1) [Mikhailov, 2013], only three units (V - Russian plain, E2 - Caucasus and $\mathrm{P}$ - mountains of South Siberia) have more reported species than the continental Russian Far East (T1). The Russian Plain (V) and the mountains of South Siberia $(\mathrm{P})$ each comprise a much larger area than T1. Although the number of species known in T1 is rather high, many species described or reported from this region remain nomina dubia, as well as being wrongly identified or poorly known. Most of the nomina dubia were caused by Grube [1861] who described 46 species from East Siberia and the Russian Far East. Descriptions are very brief (as was common at that time), have no accompanying illustrations, and are often based on juveniles. Additionally, many of the types are lost or have not yet been found. Because of this, Prószyński [1971] even suggested rejecting the names of two species of jumping spiders Attus dimidiatus Grube, 1861 and $A$. fuscostriatus Grube, 1861, ignoring the fact that most species described in the18th and first half of the 19th centuries lack types and their descriptions are inadequate. As a result, 10 of 46 species described by Grube are considered nomina dubia. A similar situation occurred with Araneus Clerck, 1758 species described by Bakhvalov [1981] (poor descrip- tions, lack of types), but all of these species are currently recognized and have been redescribed or synonymised [Šestáková et al., 2014; Marusik et al., 2015].

While preparing a check-list of spiders from the southern part of the Russian Far East, we recognized that some taxa supposedly occurring there have unclear statuses or are synonyms. The aims of this paper are to: 1) survey Grube's nomina dubia, 2) fix the status of two genera and 3) synonymize several species names.

\section{Material and methods}

Because types of 10 species described by Grube [1861] from the Russian Far East cannot be located, their descriptions are very brief, they were never redescribed and are considered nomina dubia, we decided to synonymize them based on: 1) checking the original description and 2) analyzing species known from or near the type locality. If several similar looking spiders occur in the area, we synonymized them with the older (senior) names to avoid extra nomenclatorial acts (such as suppression of old names). Two nomina dubia, Ciniflo flavovittata Grube, 1861 and C. lunigerus Grube, 1861, described from the Amur River are not considered here because authors have no information on their status. Microphotographs were made with 
a Jeol JSM-5200 SEM in the Zoological Museum, University of Turku, Finland.

\section{Taxonomic Survey}

\section{LINYPHIIDAE}

\section{Hypomma bituberculatum (Wider, 1834)}

Micryphantes miniatus Grube, 1861: 167 (†). Syn.n.

Comments. Micryphantes miniatus was described based on one female from Nikolaevsk (Nikolaevsk-naAmure). The type material is not found. Judging from the prosoma coloration (red) and the size, it can be synonymized with the Transpalaearctic $H$. bituberculatum.

Megalepthyphantes nebulosus (Sundevall, 1830)

Linyphia melanopleuros Grube, 1861: 167 (†). Syn.n.

Comments. The holotype female of Linyphia melanopleuros described from De Castri Bay is not found. Judging from the brief description, including the size and pattern, and the distribution, we conclude that Grube's species can be synonymized with Megalepthyphantes nebulosus, a species also known from Khabarovsk Province.

Neriene emphana (Walckenaer, 1841)

Linyphia albomaculata Grube, 1861: 166 (+). Syn.n.

Comments. The holotype female of Linyphia albomaculata described from De Castri Bay is not found. Judging from the brief description, including size and pattern, and the type locality, we consider Linyphia albomaculata a junior synonym of Neriene emphana, a species distributed across the southern part of the Russian Far East.

Silometopoides Eskov, 1990

Silometopoides Eskov, 1990: 52 (type Minyriolus pampia Chamberlin, 1949, from Buffin Island, Canada).

Orientopus Eskov, 1992: 165 (type Lophomma yodoense Oi, 1960, from Japan). Syn.n.

Comments. Silometopoides was described as a monotypic genus based on specimens from Mongolia. Silometopoides. pampia was thought to be widely distributed across Siberia and Arctic Canada; however, later it was found that it occurs only in the Nearctic and adjacent Chukotka, whereas populations from Siberia and Mongolia belong to three separate species [Eskov, Marusik, 1992]. Further revision of the East Palaearctic Erigoninae revealed that four species previously placed in Silometopus Simon, 1926 and Lophomma Menge, 1868 belong to Silometopoides [Marusik et al. 2001]. Whereas Lophomma yodoense was transferred to Silometopoides by Marusik et al. [2001], it was overlooked that a monotypic genus, Orientopus Eskov, 1992, had previously been created for this species. Because the two genera were not synonymized, Plat- nick [2001-2014] has not accepted the transfer of Lophomma yodoense into Silometpoides.

When Eskov [1992] created a new genus, he had not studied any specimens and his description was based on the literature. Examination of Orientopus yodoensis from Kunashir and Shikotan Islands as well as from Primorie reveals that this species is certainly closely related to Silometopoides pampia, and therefore, the two genera should be synonymized.

Silometopoides yodoensis (Oi, 1960) comb.n.

Orientopus y.: Song et al., 1999: 199, f. 114C-E (O'P); Ono et al., 2009: 267, f. 100-104 (O'P)

Comments. The species is well-described in the abovementioned papers. It is transferred to Silometopoides because of the synonymization of the two genera.

Distribution. Palaearchaearctic range; known from the Maritime Province, Kunashir and Shikotan Islands in Russia (unpubl. data), Honshu Island (Japan), Korea and Hebei Province in China [Song et al., 1999].

\section{Theoneta Eskov et Marusik, 1991 stat.n.} Figs $1-4$.

Theoneta Eskov et Marusik, 1991: 242, described as subgenus of Microneta, type Microneta (Theoneta) saaristoi Eskov et Marusik, 1991 from Magadan Area.

Theoneta: Saaristo et Tanasevitch, 1996: 175 (mentioned among Micronetinae genera).
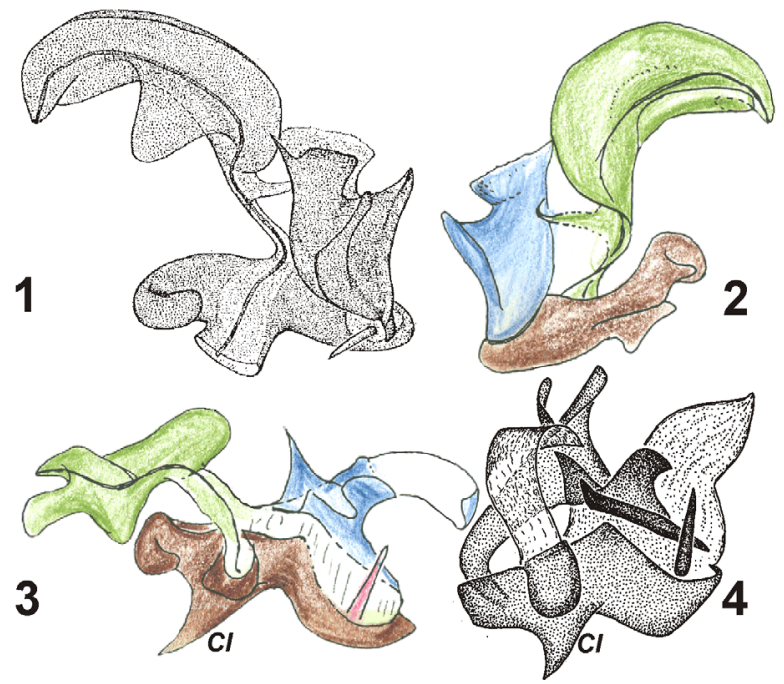

Figs 1-4. Comparison of embolic division in Microneta and Theoneta. 1-2 - M. viaria, ventral and dorsal; 3 - Th. saaristoi, ventral; 4 - Th. aterrima, ventral. 1 - after Saaristo [1974]; 2-3 — after Marusik \& Koponen [2008]; 4 - after Eskov \& Marusik [1991]. Abbreviation: $\mathrm{Cl}$ - claw-like outgrowth.

Рис. 1-4. Сравнение эмболюсного отдела у Microneta и Theoneta. 1-2 - M. viaria, вентрально и дорзально; $3-T$. saaristoi, вентрально; 4 - T. aterrima, вентрально. 1 - по Saaristo [1974], 2-3 - по Marusik \& Koponen [2008], 4 - по Eskov \& Marusik [1991]. Сокращения: $\mathrm{Cl}$ - когтевидный вырост. 
Comments. Theoneta was described as a subgenus of Microneta Menge, 1869 with two new species from Eastern Siberia. While surveying Micronetinae, Saaristo \& Tanasevitch [1996] listed Theoneta as a genus of the subfamily, but this new status was not discussed or commented on or illustrated. The two genera have a similar small spine-like lamella characteristica, and are well-differntiated by the shape of the epigyne and clawlike $(\mathrm{Cl})$ outgrowth of the radix (Figs 1-4). Theoneta differs from Microneta also by somatic characters: the presence of a trichobothrium on metatarsus IV (lacking in Microneta) and lacking the laterial spine on tibia I (present in Microneta).

Composition. Theoneta aterrima Eskov et Marusik, 1991 and T. saaristoi Eskov et Marusik, 1991.

\section{LYCOSIDAE}

Pardosa hanrasanensis Jo et Paik, 1984, sp. revalid. Figs 9-14.

P. hanrasanensis Jo et Paik, 1984: 194, f. 3A-E ( ${ }^{7}+$ ).

P. bifasciata: Yu, Song, 1988: $116(+)$; Namkung, 2002: 335, f. 20.29a-b ( ( + ); Namkung, 2003: 337, f. 20.29a-b ( $\left.\sigma^{7}+\right)$.

P. hanrasanensis: Kim, Yoo, 1997: 33, f. 3, 30-31, 46 (+); Marusik, 2009: 103.

P. bukukun Logunov et Marusik, 1995: 112, f. 13-19 ( $\sigma^{7}$ ). Syn.n. Material examined: Maritime Province: $3 \sigma^{\top} \sigma^{\top}, 2$ 우 (GTS) "Zapovednoe" Marine Biological Station, shore meadows, 2124.07.2003 (M.M. Omelko); 6 우 (GTS), same locality and habitat, 21-25.07.2005 (M.M. Omelko); 3 우 (GTS), same locality and

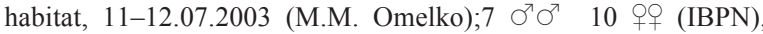
Ussuri Reserve, 4339' N 132 33'E, 29-31.07.1998 (Yu.M. Marusik); 1 (IBPN), Lazovski Reserve, Korpad' Camp, $43^{\circ} 16^{\prime} \mathrm{N}$ $134^{\circ} 08^{\prime} \mathrm{E}, 6-9.08 .1998$ (Yu.M. Marusik).

Comments. Pardosa hanrasanensis was decribed from Korea. Soon after, it was synonymized with $P$. bifasciata (C.L. Koch, 1834) without comparing the Korean specimens to specimens from the type locality in Germany. Notably, P. bifasciata is unknown in Eastern China an areas adjacent to Korea [cf. Song et al., 1999], but is known from Xinjiang to Gansu, and from Tibet to Sichuan.

A study of the bifasciata-group (Marusik, unpubl. data) revealed that $P$. bifasciata occurs in the West Palaearcrtic only (from Europe to Tuva). Records of this species from South China may refer to the sister species $P$. thaleri Buchar, 1976.

Side by side comparison of specimens from Europe and from the Russian Far East revealed that $P$. hanrasanensis is well-differentiated from $\mathrm{P}$. bifascita by copulatory organs (cf. Figs 6-8, 15-17); the palp shape is more similar to P. schenkeli (Fig. 5), and therefore this name should be removed from synonymy.

Pardosa bukukun was described from the east part of Chita Area. This species was compared in detail with $P$. schenkeli Lessert, 1904, the only species of the bifasciata-group known from Eastern Siberia at that time. Later, when females of $P$. hanrasanensis were found in the Maritime Province [Marusik, 2009], it became evident that $P$. bukukun should possibly be synonymized with $P$. hanrasasensis. Later, males of $P$. hanrasanensis found in the Maritime Province were compared with paratypes of $P$. bukukun; we concluded that two names should be synonymized.

Distribution. This species has a Manchurian range and is known from the Chita Area east to the Maritime Province and south to Korea. Its occurrence in NE China is very likely. A record of this species from Altai [Trilikauskas, Ponomareva, 2013] most likely refers to P. bifasciata.

\section{SALTICIDAE}

Carrhotus xanthogramma (Latreille, 1819)

Attus dimidiatus Grube, 1861: $179(+)$. Syn.n.

Comments. The species was described based on a single female from the Amur River opposite to Ussuri River mouth [Grube, 1861], or just on the left bank of the Amur River opposite Khabarovsk. The type specimen is not located [Prószyński, 1971], but judging from the description (pattern and size), A. dimidiatus can be synonymised with Carrhotus xanthogramma, also from the vicinity of Khabarovsk.

Distribution. This species has Transpalaearctic range.

Neon reticulatus (Blackwall, 1853)

Attus fuscostriatus Grube, 1861: 178 ( $($ ). Syn.n.

Comments. Attus fuscostriatus was described based on the holotype female collected on the Amur River opposite to the Ussuri River mouth [Grube, 1861]. The type specimen is not located and this species was never redescribed. Judging from the small size $(3 \mathrm{~mm})$ and coloration, we conclude that it is Neon reticulatus, a species known from the vicinity of Khabarovsk (mouth of Ussuri River) [Marusik et al., 2007]. Therefore, we synonymized the two names.

Distribution. This species has a Transpalaearctic West Nearctic range.

\section{Sitticus distinguendus (Simon, 1868)}

Attus viduus Kulczyński, 1895: 79, pl. 2, f. 28-29 (○’; praeocc. by Walckenaer, 1847). Syn.n.

S. numeratus Bösenberg et Strand, 1906: 342, pl. 9, f. 138, pl. 13, f. 359 ( $\left.\sigma^{\top}+\right)$. Syn.n.

S. sibiricus Roewer, 1951: 453 (replacement name for Attus viduus). Syn.n.

S. paraviduus Schenkel, 1963: 402, f. 232a-c ( ( $\left.{ }^{7}\right)$. Syn.n.

S. d.: Logunov, Marusik, 2000a: 207, map 43; Logunov, Marusik, 2000b: 270, f. 26-27, 29, 32-33 ( $\left.\mathrm{O}^{7}+\right)$

Comments. Four names listed above, viduus, numeratus, sibiricus and paraviduus, are currently considered junior synonyms of $S$. avocator (O. PickardCambridge, 1885) [Platnick, 2000-2014; Proszyñski, 2014; WSC, 2015]. The type localities of these species (Cisbaikalia, Japan and Central China) are outside the range of $S$. avocator: mountains of Central Asia [map 47: Logunov, Marusik, 2000a], but are within the range of the Transpalaearctic S. distinguendus. Therefore, 

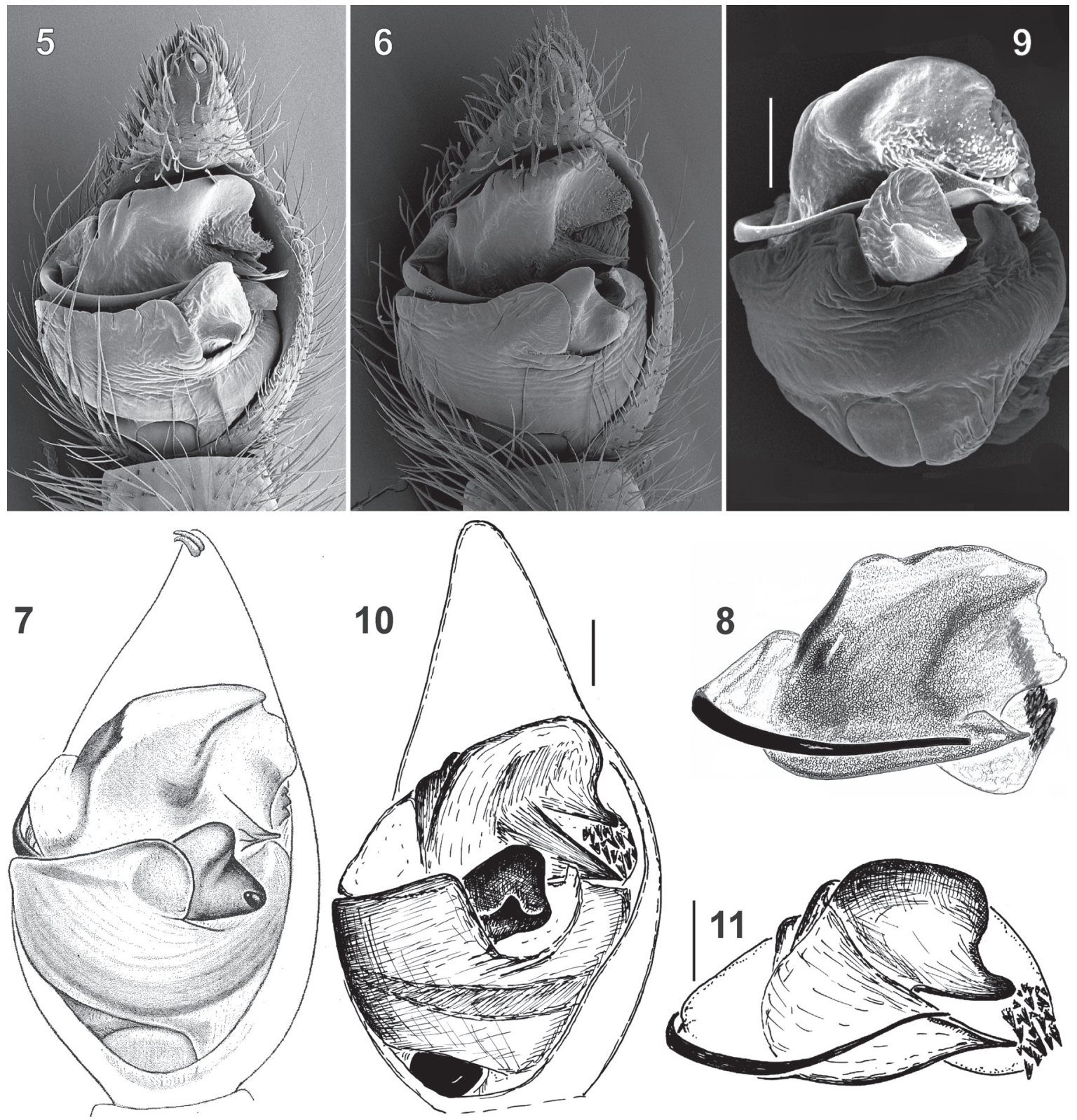

Figs 5-11. Male palp of Pardosa schenkeli (5), P. bifasciata (6-8) and P. hanrasanensis (9-11). 5-7, 10 - total palp, ventral; 8 (from Austria), 11 - embolic division, ventral; 9 - bulb, ventral. Scale $0.1 \mathrm{~mm}$. 5-6 - orig., made by T. Kronestedt; 7 - after Kronestedt [2006]; 10-11 - paratype of P. bukukun, after Logunov \& Marusik [1995].

Рис. 5-11. Пальпа самца Pardos schenkeli (5), P. bifasciata (6-8) и P. hanrasanensis (9-11). Масштаб 0-,1 мм. 5-7, 10 - целая пальпа, вентрально; 8 (экземпляр из Австрии), 11 - эмболюсный отдел, вентрально; 9 - бульбус, вентрально. 5-6 - оригинал, T. Kronestedt, 7 - по Kronestedt [2006], 10-11 — по Logunov \& Marusik [1995] паратип P. bukukun.

these four names should be removed from synonymy with $S$. avocator and considered synonyms of $S$. distinguendus. Moreover, syntype male of $S$. sinensis Schenkel, 1963 described from the same region as $S$. paraviduus has no differences with $S$. distinguendus.

Sitticus distinguendus was reported from the Russian Far East under the names $S$. viduus [Prószyński, 1979], S. avocator [Nenilin, 1985; Logunov, 1998], and $S$. distinguendus.
Distribution. Transpalaearctic nemoral range.

\section{THERIDIIDAE}

Phoroncidia pilula (Karsch, 1879)

Figs 18-20.

Sudabe pilula Karsch, 1879: 63 ().

Ulesanis minschana Schenkel, 1936: 49, f. 15 ( $\left.\bigcirc^{7}+\right)$. Syn.n. 

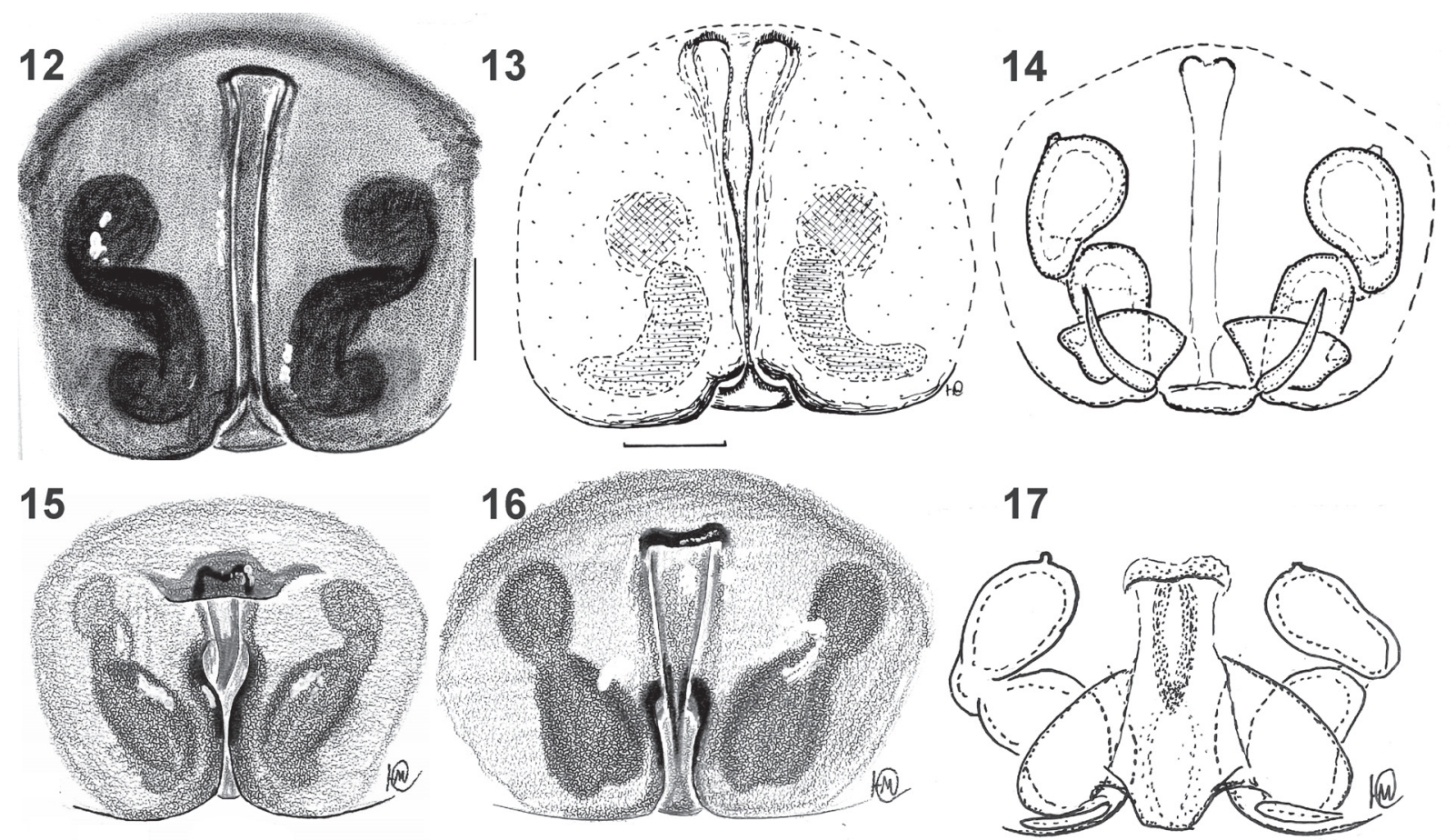

Figs 12-17. Epigyne of Pardosa hanrasanensis (12-14) and P. bifasciata (15-17). 12-13, 15-16 - ventral; 14, 17 — dorsal. $12-14$ paratypes of $P$. bukukun, after Logunov \& Marusik [1995]; 15, 17 - from Austria; 16 - from Tuva.

Рис. 12-17. Эпигина Pardos hanrasanensis (12-14) и P. bifasciata (15-17). 12-13, 15-16 - вентрально, 14, 17 — дорзально. 12-14 - паратипы P. bukukun, по Logunov \& Marusik [1995]; 15, 17 - из Австрии; 16 - из Тувы.
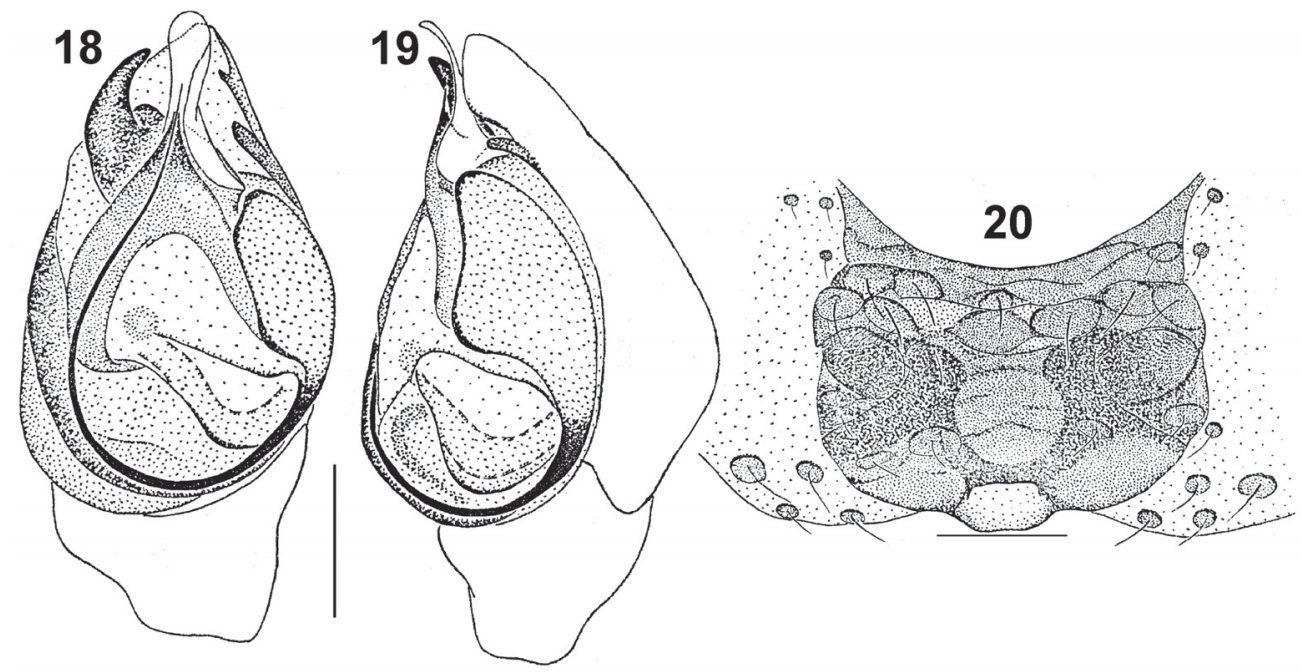

Figs 18-20. Copulatory organs of Phoroncidia pilula (after Logunov \& Marusik [1992]). 18-19 - male palp, ventral and retrolateral; 20 - epigyne, ventral. Scale $0.1 \mathrm{~mm}$.

Рис. 18-20. Копулятивные органы Phoroncidia pilula (по Logunov \& Marusik [1992]). 18-19 — пальпа самца, вентрально и ретролатерально; 20 - эпигина, вентрально. Масштаб 0,1 мм.

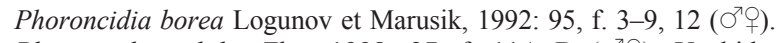
Phoroncidia pilula: Zhu, 1998: 27, f. 11A-D ( $\left.\bigcirc^{7}+\right)$; Yoshida,

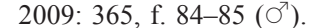

For complete list of references see World Spider Catalog [2015].

Material examined: RUSSIA: Maritime Province; $10^{7} 1$ 옹

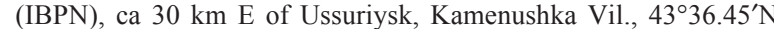

$132^{\circ} 13.60^{\prime} \mathrm{E}, 30.08 .2001$ (Yu.M. Marusik). Sakhalin Area: $1 \mathrm{O}^{\top} 1$
ㅇ (IBPN), Kuril Islands: Kunashir Island, S part, $2.5 \mathrm{~km} \mathrm{~N}$ of Golovnino, $145^{\circ} 32.02^{\prime} \mathrm{E} 43^{\circ} 46.01^{\prime} \mathrm{N}$, oak forest with a few birches and bamboo, 1.09.1997 (Yu.M. Marusik).

Remarks. Ulesanis minschana was described from the Gansu Province of China. This species, for uncertain reasons, was not treated in the revision of Chinese 
Theridiidae, but in the text [Zhu, 1998: 27] it was mentioned that it should be transferred to Phoroncidia. Zhu [1998] has not established a new combination and he was not aware that $U$. minschana was already considered Phoroncidia by Logunov \& Marusik [1992] and Logunov [1992]. Logunov \& Marusik [1992] described $P$. borea from the environs of Khabarovsk. Comparison of this species with the types of $P$. minschana revealed that they are conspecific and the two names were synonymized [Logunov, 1992]. Although $P$. pilula was considered in 19 taxonomical publications and was illustrated in 14 papers [cf. Platnick, 2014], proper detailed illustrations of the male palp are lacking. A comparison of figures of $P$. minschana from Logunov \& Marusik [1992] and specimens from Japan (Tanikawa, pers. comm.) revealed no differences, and therefore the two names should be synonymized. This conclusion is additionally supported by the recording of $P$. pilula from Gansu (type locality of $P$. minschana) and Liaoning (a province close to the Russian Far East) [Song et al., 1999].

Distribution. This species has a Palaearchaearctic range and occurs in Japan, NE China, Korea and the Russian Far East (Kunashir Island and the vicinity of Khabarovsk). Within Russia it was previously known from the Bolshekhekhtsyrskiy Reserve in Khabarovsk Province (the northermost record of the species and the entire genus).

\section{Steatoda albomaculata (De Geer, 1778)}

\section{Asagena amurica Strand, 1907: 132 (+). Syn.n.}

Steatoda amurica: Mikhailov, 1996: 82.

Comments. Asagena amurica was described from Blagoveshchensk. Mikhailov [1996] transferred it to Steatoda Sundevall, 1833 by synonymizing Asagena Sundevall, 1833 with Steatoda. Steatoda amurica is known only from the original description. Its type was not examined and the species was never illustrated. Although the author described the female, judging from the text "Eine Epigyne scheint noch nicht entwickelt zu sein", the holotype is a subadult female. Strand compared his species with $S$. phalerata and $S$. japonica Bösenberg et Strand, 1906 [a probable synonym of $S$. albomaculata (De Geer, 1778)]. Based on the original description "Abdomen schwarz, schwach rötlich angeflogen, oben mit unter sich ziemlich entfernt stehenden, gewissermassen in Reihen angeordneten, feinen graulichen Pünktchen gezeichnet, sowie mit zwei parallelen oder ganz schwach nach hinten divergierenden Reihen ..." (=abdomen with two rows of dots), it is more likely that $S$. amurica is conspecific with the Holarctic S. albomaculata.

Distribution. The species has Circumholarctic range.

ACKNOWLEDGEMENTS. We thank Akio Tanikawa (Tokyo, Japan) for consultations dealing with Phoroncidia pilula; Torbjörn Kronestedt (Stockholm, Sweden) for providing us with SEM figures of Par- dosa bifasciata and P. schenkeli and Seppo Koponen for allowing us to use facilities in the Zoological Museum, University of Turku. English of the final draft was kindly checked and edited by Sarah Crews (Oakland, California, USA). This work was supported in part by the Russian Foundation for Basic Research (grants Nos 12-04-01548 and 14-14-00701) and the Far Eastern Federal University. Proceeding of this paper is supported by Russian Science Foundation project No. 1450-00029.

\section{References}

Bakhvalov V.F. 1981. [New species of orb-weaving spiders (Aranei, Araneidae) from Siberia and Soviet Far East] // Entomologicheskie issledovaniya v Kirghizii. Frunze. Vol.14. P.142150 [in Russian].

Bösenberg W., Strand E. 1906. Japanische Spinnen // Abhandlungen der Senckenbergischen naturforschenden Gesellschaft. Bd.30. S.93-422.

Eskov K.Yu. 1990. [New monotypic genera of the spider family Linyphiidae (Aranei) from Siberia: Communication 2] // Zoologicheskii Zhurnal. Vol.69. No.1. P.43-53 [in Russian, with English summary].

Eskov K.Y. 1992. A restudy of the generic composition of the linyphiid spider fauna of the Far East (Araneida: Linyphiidae) // Entomol. Scand. Vol.23. P.153-168.

Eskov K.Y., Marusik Y.M. 1991. New linyphiid spider (Aranei, Linyphiidae) from east Siberia // Korean Arachnol. Vol.6. No.2. P.237-253.

Eskov K.Y., Marusik Y.M. 1992. On the Siberio-Nearctic erigonine spider genus Silometopoides (Araneida: Linyphiidae) // Reichenbachia. Vol.29. P.97-103.

Grube A.E. 1861. Beschreibung neuer, von den Herren L. v. Schrenck, Maack, C. v. Ditmar u. a. im Amurlande und in Ostsibirien gesammelter Araneiden // Bulletin de l'Académie impériale des sciences de St.-Pétersbourg. Vol.4. P.161-180.

Jo T.H., Paik K.Y. 1984. Three new species of genus Pardosa from Korea (Araneae: Lycosidae) // Korean Journal of Zoology. Vol.27. P.189-197.

Karsch F. 1879. Baustoffe zu einer Spinnenfauna von Japan // Verhandlungen des Naturhistorischen Vereins der Preussischen Rheinlande und Westfalens. Bd.36. S.57-105.

Kim J.P., Yoo J.S. 1997. Korean spiders of the genus Pardosa C.L. Koch, 1848 (Araneae: Lycosidae) // Korean Arachnol. Vol.13. No.1. P.31-45.

Kronestedt T. 2006. On Pardosa schenkeli (Araneae, Lycosidae) and its presence in Germany and Poland // Arachnol. Mitt. H.32. P.31-37.

Kulczyński W. 1895. Attidae musei zoologic Varsoviensis in Siberia orientali collecti // Rozprawy Wydzia ${ }^{3} u$ MatematycznoPrzyrodniczego Akademii Umiejêtnoœci, Cracovie. T.32. P.4598.

Logunov D.V. 1992. [On the spider fauna of the Bolshekhekhtsyrski State Reserva (Khabarovsk Province). I. Families Araneidae, Lycosidae, Philodromidae, Tetragnathidae, Theridiidae and Thomisidae] // Sibirskii biologicheskii zhurnal. Vol.4. P.5668 [in Russian, with English summary].

Logunov D.V. 1998. New species and new records of Palaearctic Sitticus (Araneae: Salticidae) // Zoosystematica Rossica. Vol.7. P.77-83.

Logunov D.V., Marusik Y.M. 1992. [The spider genus Phoroncidia (Aranei, Theridiidae) in the USSR] // Ovtsharenko V.I. (ed.). Fauna in ekologiya paukov, skorpionov i lozhnoskorpionov SSSR. Trudy Zoologicheskogo Instituta AN SSSR. Leningrad. Vol.226. P.91-97 [in Russian, with English summary].

Logunov D.V., Marusik Y.M. 1995. Spiders of the family Lycosidae (Aranei) from the Sokhondo Reserve (Chita Area, East Siberia) // Beiträge zur Araneologie. Vol.4. P.109-122. 
Logunov D.V., Marusik Yu.M. 2000a. Catalogue of the jumping spiders of northern Asia (Arachnida, Araneae, Salticidae). Moscow: KMK Scientific Press Ltd. 299 pp.

Logunov D.V., Marusik Yu.M. 2000b. Miscellaneous notes on Palaearctic Salticidae (Arachnida: Aranei) // Arthropoda Selecta. Vol.8. No.4. P.263-292.

Marusik Yu.M. 2009. A check-list of spiders (Aranei) from the Lazo Reserve, Maritime Province, Russia // Arthropoda Selecta. Vol.18. No.1-2. P.95-109.

Marusik Yu.M., Koponen S. 2008. Obituary. Michael Ilmari Saaristo (1938-2008) // Arthropoda Selecta. Vol.17. No.1-2. P.4-16.

Marusik Y.M., Koponen S., Danilov S.N. 2001. Taxonomic and faunistic notes on linyphiids of Transbaikalia and south Siberia (Araneae, Linyphiidae) // Bull. Brit. Arachnol. Soc. Vol.12. Pt.2. P.83-92.

Marusik Yu.M., Omelko M.M., Simonov P.S., Koponen S. 2015 (submitted). A new data about orb-weaving spiders (Aranei: Araneidae and Tetragnathidae) from the Russian Far East // Arthropoda Selecta. Vol.24.

Marusik Y.M., Tanasevitch A.V., Kurenshchikov D.K., Logunov D.V. 2007. A check-list of the spiders (Araneae) of the Bolshekhekhtsyrski Nature Reserve, Khabarovsk Province, the Russian Far East // Acta arachnologica sinica. Vol.16. No.1. P.37-64.

Mikhailov K.G. 1996. A checklist of the spiders of Russia and other territories of the former USSR // Arthropoda Selecta. Vol.5. No.1/2. P.75-137.

Mikhailov K.G. 2013. The spiders (Arachnida: Aranei) of Russia and adjacent countries: a non-annotated checklist // Arthropoda Selecta. Supplement No.3. 262 p.

Namkung J. 2002.The spiders of Korea. Seoul: Kyo-Hak Publishing Co. 648 pp.

Namkung J. 2003. The Spiders of Korea. 2nd. ed. Seoul: Kyo-Hak Publ. Co. 648 pp.

Nenilin A.B. 1985. [Materials on the fauna of the spider family Salticidae of the USSR. II. Results of the study in the USSR] / / Ovtsharenko V.I. (ed.). Fauna i ekologiya paukov. Trudy Zoologicheskogo Instituta AN SSSR. Leningrad. Vol.139. P.129-134 [in Russian, with English summary].

Ono H. 2009. The Spiders of Japan with keys to the families and genera and illustrations of the species. Kanagawa: Tokai University Press. 739 pp. [in Japanese]

Ono H., Matsuda M., Saito H. 2009. Linyphiidae, Pimoidae // Ono H. (ed.). The Spiders of Japan with keys to the families and genera and illustrations of the species. Kanagawa: Tokai University Press. P.253-344 [in Japanese].

Platnick N.I. 2014. The World Spider Catalog, Version 15. American Museum of Natural History, New York; online at http:// research.amnh.org/iz/spiders/catalog/ (accessed February 10, 2015).

Prószyński J. 1971. Redescriptions of the A. E. Grube's East Siberian species of Salticidae (Aranei) in the collection of the Wroclaw Zoological Museum // Annales Zoologici, Warszawa. T.28. No.11. P.205-226.
Prószyński J. 1979. Systematic studies on East Palearctic Salticidae III. Remarks on Salticidae of the USSR // Annales Zoologici (Warsaw). T.34. P.299-369.

Proszyński J. 2014.Salticidae (Araneae) of the World; online at http://www.peckhamia.com/salticidae/ (accessed February 10, 2015).

Roewer C.F. 1951. Neue Namen einiger Araneen-Arten // Abhandlungen Naturwissenschaftlicher Verein Bremen. Bd1.32. S.437456.

Saaristo M. I. 1974. Taxonomical analysis of Microneta viaria (Blackwall, 1841), the type-species of the genus Microneta Menge, 1869 (Araneae, Linyphiidae) // Ann. Zool. Fenn. Vol.11. P.166-169.

Saaristo M.I., Tanasevitch A.V. 1996. Redelimitation of the subfamily Micronetinae Hull, 1920 and the genus Lepthyphantes Menge, 1866 with descriptions of some new genera (Aranei, Linyphiidae) // Berichte des naturwissenschaftlich-medizinischen Vereins in Innsbruck. Vol.83. P.163-186.

Schenkel E. 1936. Schwedisch-chinesische wissenschaftliche Expedition nach den nordwestlichen Provinzen Chinas, unter Leitung von Dr Sven Hedin und Prof. Sü Ping-chang. Araneae // Arkiv för zoologi. Bd.29(A). Nr.1. S.1-314.

Schenkel E. 1963. Ostasiatische Spinnen aus dem Muséum d'Histoire naturelle de Paris // Memoires du Museum d'Histoire Naturelle de Paris (A, Zool.). Vol.25. P.1-481.

Šestáková A., Marusik Y.M., Omelko M.M. 2014. A revision of the Holarctic genus Larinioides Caporiacco, 1934 (Araneae: Araneidae) // Zootaxa. Vol.3894. No.1. P.61-82.

Seyfulina R.R. 2006. A contribution to the knowledge of the spider fauna (Arachnida: Aranei) of Russia: new records for the Amur area // Arthropoda Selecta. Vol.14. No.3. P.271-279.

Song D.X., Zhu M.S., Chen J. 1999. The Spiders of China. Shijiazhuang: Hebei Sci. Technol. Publ. House. 640 pp.

Strand E. 1907. Süd- und ostasiatische Spinnen // Abhandlungen und Berichte Naturforschende Gesellschaft zu Gorlitz. Bd.25. S.107-215.

Trilikauskas L.A., Ponomareva S.M. 2013. [On the spider population of the environs of Teletskoe Lake (North-East Altai)] // Sibirskiy ekologicheskiy zhurnal. No.6. P.867-876 [in Russian, with English summary].

Yoshida H. 2009. Theridiidae // Ono H. (ed.). The Spiders of Japan with keys to the families and genera and illustrations of the species. Kanagawa: Tokai Univ. Press. P.356-393 [in Japanese].

World Spider Catalog (2015). World Spider Catalog. Natural History Museum Bern, online at http://wsc.nmbe.ch, version 16, accessed on January 15, 2015.

Yu L.M., Song D.X. 1988. A revision of the Chinese spiders of the family Lycosidae (Araneae) // Sinozoology. Vol.6. P.113-121.

Zhu M.S. 1998. Fauna Sinica: Arachnida: Araneae: Theridiidae. Beijing: Science Press. 436 pp. [In Chinese]

Responsible editor $S$. Koponen 